\title{
PENGARUH PEMBERIAN AIR SEDUHAN DAUN SIRIH (Piper betle L.) TERHADAP PERBAIKAN HISTOLOGI HEPATOSIT TIKUS PUTIH STRAIN WISTAR (Rattus novergicus strain wistar) YANG TELAH DIINDUKSI PARASETAMOL
}

\author{
Nur Aisyah ${ }^{1}$, Meddy Setiawan ${ }^{2}$, Moch Aleq Sander ${ }^{3}$ \\ Fakultas Kedokteran Universitas Muhammadiyah Malang, Jl. Bendungan Sutami No. 188A, Kota Malang, \\ 65145, Indonesia, (0341)551149
}

\begin{abstract}
ABSTRAK
PENGARUH PEMBERIAN AIR SEDUHAN DAUN SIRIH (Piper betle L.) TERHADAP PERBAIKAN HISTOLOGI HEPATOSIT TIKUS PUTIH STRAIN WISTAR (Rattus novergicus strain wistar) YANG TELAH DIINDUKSI PARASETAMOL. Parasetamol dapat merusak hepatosit oleh hasil metabolismenya yang reaktif berupa Nasetil-p-benzokuinone imine (NAPQI) dan ion superoksida. Daun sirih diduga dapat memperbaiki kerusakan hepatosit karena mengandung minyak atsiri yang mempunyai aktivitas antioksidan. Tujuan: Membuktikan pengaruh pemberian air seduhan daun sirih terhadap perbaikan histologi hepatosit tikus putih strain wistar yang telah diinduksi parasetamol. Metode penelitian: True Experimental post test only control Design. Dua puluh lima tikus putih strain wistar dengan berat badan masing-masing 150 gram dibagi menjadi 5 kelompok perlakuan. Masing-masing kelompok diberi $375 \mathrm{mg}$ parasetamol peroral selama 4 hari. Tiga kelompok diberi air seduhan daun sirih peroral dengan 3 dosis berbeda. Dosisnya adalah $45 \mathrm{mg}, 67,5 \mathrm{mg}$ dan $90 \mathrm{mg}$ selama 12 hari. Hasil penelitian: Uji one way Anova $(\mathrm{p}=0,000<0,01)$ menunjukkan ada perbedaan prosentase kerusakan hepatosit yang sangat signifikan pada masingmasing kelompok. Penurunan prosentase kerusakan hepatosit paling signifikan pada kelompok dengan dosis air seduhan daun sirih paling besar (90 mg). Kesimpulan: Pemberian air seduhan daun sirih dapat memperbaiki kerusakan hepatosit pada tikus yang diinduksi dengan parasetamol. Penambahan dosis air seduhan daun sirih menurunkan jumlah kerusakan hepatosit.
\end{abstract}

\section{ABSTRACT}

The Effect of Betel Leaf (Piper betle L.) Steeping Water to Hepatocyte Histologic Repair in Strain Wistar White Mice (Rattus Novergicus Strain Wistar) Induced by Paracetamol. Paracetamol can damage hepatocyte due to N-acetyl-benzoquinone imine (NAPQI) and superoxide ion as their reactive metabolism product. Betel leaf contains atsiri oil that has antioxidant activity could be repair hepatocyte damage. Objective: To prove the effect of betel leaf steeping water to hepatocyte histologic repaired in strain wistar white mice induced by paracetamol. Methods: True Experimental post test only control Design was used. Twenty five mice with body weight 150 gram each were divided into 5 groups. Each group was given $375 \mathrm{mg}$ paracetamol orally for 4 days. Three groups were given betel leaf steeping water orally with 3 different doses. The dose were $45 \mathrm{mg}, 67,5 \mathrm{mg}$ and $90 \mathrm{mg}$ for 12 days. Results: One way Anova test showed $(p=0,000<0,01)$ that there were different percentage of hepatocyte damage which was very significant. The decrease percentage of hepatocyte damage most significant in group with the highest dose of betel leaf steeping water $(90 \mathrm{mg})$. Conclusion: Betel leaf steeping water can repair hepatocyte damage of mice that induced by paracetamol. The increases dose of betel leaf steeping water decrease amount of hepatocyte damage.

Key words: Paracetamol, NAPQI, Betel leaf, Antioxidant, Hepatocyte, Mice.

\section{PENDAHULUAN}

Penyakit pada hati merupakan salah satu penyakit di Indonesia yang mempunyai prevalensi yang cukup tinggi (Ulfa, 2008). Di Indonesia, penyakit hati menempati urutan ketiga penyebab kematian setelah penyakit infeksi dan paru (Ihsan, 2007).

Kejadian kerusakan hati akibat zat yang mempunyai efek toksik pada hati, atau biasa disebut hepatotoksin, kemungkinan besar bisa terjadi di masyarakat. Hepatotoksin dapat menyebabkan hepatotoksisitas berupa kerusakan hati akut, sub kronik, dan kronik. Hepatotoksisitas adalah istilah yang dipakai untuk menggambarkan kerusakan hati akibat penggunaan obat (Ulfa, 2008). Salah satu contoh obat tersebut adalah parasetamol yang termasuk obat analgetik- antipiretik yang meluas di masyarakat, termasuk golongan obat berlabel bebas terbatas yang bisa dibeli secara bebas dan harganya sangat terjangkau (Zuraidah, 2000; Heirmayani, 2007 dan Pakarti, 2009).

Berbagai penelitian telah berhasil membuktikan bahwa beberapa obat bahan alam sangat efektif untuk digunakan pada kondisi peradangan jaringan hati. Salah satunya tanaman yang dipakai sebagai pengobatan tradisional adalah daun sirih (Piper betle L.) yang mengandung minyak atsiri yang berfungsi sebagai antioksidan. Sirih merupakan salah satu tanaman obat yang mempunyai wilayah persebaran yang sangat luas di Indonesia. Daun sirih juga telah lama digunakan dalam pengobatan tradisional misalnya sebagai obat kumur dan pengobatan luka (Isadiartuti, 2006). 
Minyak atsiri yang terkandung dalam daun sirih dapat membantu regenerasi hepatosit (sel hati) yang rusak ditandai dengan penurunan kadar serum glutamic-pyruvic transaminase (SGPT), serum glutamic-oxaloacetic transaminase (SGOT) dan bilirubin (Saravanan, 2002).

Obat yang berasal dari bahan alami ini relatif lebih aman, murah dan mudah diperoleh, karena dapat disediakan sendiri di rumah dengan proses pembuatan yang sederhana, yaitu dengan membuat seduhan. Walaupun konsumsi daun sirih segar langsung dimakan lebih baik karena tidak ada kerusakan senyawa, tapi masyarakat sekarang tidak banyak melakukannya karena rasa dari daun sirih itu sendiri dan konsumsinya lebih mudah diminum daripada dikunyah. Pembuatan seduhan memudahkan masyarakat dalam mengkonsumsi daun sirih. Selain caranya yang sederhana, cara ini banyak dilakukan oleh masyarakat karena tidak diperlukannya alat khusus untuk pembuatannya seperti pada pembuatan ekstrak dan juga kerusakan senyawa yang terjadi relatif kecil. Bentuk seduhan juga lebih cepat terserap tubuh karena dalam bentuk larutan, sedangkan jika dimakan langsung maka perlu melalui proses pencernaan dulu dalam tubuh (Damayanti, 2004 dan Djubaedah 1995).

Dosis daun sirih yang terbukti dapat menurunkan kadar SGOT, SGPT, GGT dan bilirubin secara signifikan pada penelitian terdahulu yang telah dilakukan adalah $60 \mathrm{mg} /$ $200 \mathrm{grBB}$ tikus/hari atau sama dengan $45 \mathrm{mg} / 150 \mathrm{grBB}$ tikus/ hari selama 12 hari setelah diinduksi parasetamol dosis toksik (Puntodewo, 2009). Yang mana dosis ini akan kita pakai sebagai dosis terkecil pada penelitian ini.

Tes darah tidak dapat memberikan semua informasi tentang keadaan hati seseorang. Mengukur viral load, tingkat enzim hati dan alpha fetoprotein (AFP) dalam darah tidak dapat menentukan apakah ada kerusakan dan seberapa tingkat kerusakannya. Untuk itu dibutuhkan pemeriksaan histologi hati (Horn, 2005).

\section{METODE PENELITIAN}

Penelitian yang digunakan adalah True Experimental Research. Penelitian ini bertujuan untuk menyelidiki kemungkinan saling hubungan sebab akibat dengan cara mengadakan intervensi atau mengenakan perlakuan kepada satu atau lebih kelompok eksperimen, kemudian hasil (akibat) dari intervensi tersebut dibandingkan dengan kelompok yang tidak dikenakan perlakuan (kelompok kontrol) (Notoatmodjo, 2010).

Desain penelitian ini adalah Posttest Only Control Group Design, yaitu rancangan eksperimen tanpa ada pengukuran awal (pretest), tetapi hanya postest saja. Pada tiap-tiap kelompok telah dirandomisasi, oleh karena itu kelompokkelompok tersebut dianggap sama sebelum dilakukan perlakuan (Notoatmodjo, 2010). Penelitian ini dilakukan pada bulan Februari tahun 2011, bertempat di Laboratorium Kimia Universitas Muhammadiyah Malang.

Pada kelompok ini terdapat 5 kelompok perlakuan yaitu satu kontrol positif A (kelompok tikus yang mendapat parasetamol dan langsung dinilai hasil akhir), satu kontrol positif B (kelompok tikus yang mendapat parasetamol kemudian diberi pakan biasa dan dinilai hasil akhir bersamaan dengan tiga kelompok perlakuan air seduhan daun sirih) dan tiga kelompok perlakuan (tikus yang mendapat parasetamol dan air seduhan daun sirih dalam tiga dosis yang berbeda). Jumlah tikus untuk 5 kelompok dengan 5 pengulangan adalah 25 ekor, ditambah cadangan 1 ekor untuk tiap kelompok, jadi total semua sampel tikus adalah 30 ekor.

Pada penelitian ini ada beberapa serangkaian tahap pelaksanaan yang harus dilakukan, antara lain aklimatisasi, yaitu menimbang berat badan tikus kemudian memberi tanda dengan cat sesuai dengan berat badannya. Pengecatan diberikan pada bagian ekor tikus agar mudah terlihat sehingga mudah dalam pengambilan, sedangkan cat yang dipakai adalah cat yang tidak menimbulkan iritasi pada kulit tikus. Kemudian memasukkan tikus dalam kandang yang terbuat dari bahan yang mudah dibongkar pasang, yaitu dari bak plastik yang ditutup dengan kawat. Hal ini dimaksudkan agar tikus tampak dari luar, sehingga mudah dalam mengamati tikus dan mengambil tikus, karena kandang dapat dibuka dan ditutup dengan mudah. Adapun bak plastik yang dipakai adalah yang tahan dari gigitan tikus, dengan ukuran panjang $35 \mathrm{~cm}$, lebar $28 \mathrm{~cm}$, dan tinggi 12 $\mathrm{cm}$. kandang juga diberi sekam sebagai alas tidur tikus, sehingga tikus merasa nyaman. Sekam sebagai alas tidur untuk tikus diganti setiap tiga hari sekali agar tidak kotor dan berbau. Sekam yang tidak sering diganti akan cepat kotor dan akan menimbulkan bau amonia yang berasal dari kencing tikus. Amonia sangat berbahaya bagi tikus karena dapat mengiritasi sistem pernapasan dan cepat menimbulkan penyakit paru-paru. Kandang yang disiapkan sebanyak 30 tempat dan masing-masing diisi tikus 1 ekor. Cara memasukkan yaitu dengan memegang badan tikus dan memasukkan satu persatu ke dalam kandang. Cara memasukkan tikus harus dengan hati-hati dan perlahanlahan agar tikus tidak merasa ketakutan dan stres, karena takut dan stres dapat mempengaruhi kerja hormonal tikus. Kemudian mengadaptasikan tikus (aklimatisasi) selama 4 hari dan selama masa ini tikus diberi makan BR1 dalam bentuk konsentrat asli tanpa ada penambahan bahan lain. Makanan yang diberikan pada tikus sebanyak 15g/ekor/ hari. Makanan diberikan dua kali sehari yaitu pagi dan sore, jika ada sisa makanan maka sisanya dibuang lalu diganti dengan yang baru, serta diberi minum aquades sebanyak et libidum.

Tikus yang sudah diaklimatisasi selama 4 hari dikelompokkan untuk dilakukan perlakuan, dimana pengelompokan dilakukan secara random (acak), dengan cara mengambil tikus secara acak lalu menaruh pada kandangkandang yang sudah disediakan dimana dalam satu kandang diisi tikus sebanyak 1 ekor dan kandang yang digunakan sebanyak 30 buah. Setelah itu memberi label pada masingmasing kandang sesuai perlakuan yaitu 6 kandang dengan label $\mathrm{K}+\mathrm{A}$ (untuk yang diberi parasetamol dengan dosis $375 \mathrm{mg} / 150 \mathrm{grBB}$ tikus/hari selama 4 hari langsung dinilai), 6 kandang dengan label $\mathrm{K}+\mathrm{B}$ (untuk yang diberi parasetamol dengan dosis $375 \mathrm{mg} / 150 \mathrm{grBB}$ tikus/hari selama 4 hari dan diberi pakan seperti biasa tanpa air seduhan daun sirih selama 12 hari), 6 kandang dengan label K1 (untuk yang diberi parasetamol dosis $375 \mathrm{mg} / 150 \mathrm{grBB}$ tikus/hari + air seduhan daun sirih dosis $45 \mathrm{mg} / 150 \mathrm{grBB}$ tikus/hari), 6 kandang dengan label K2 (untuk yang diberi parasetamol 
dosis $375 \mathrm{mg} / 150 \mathrm{grBB}$ tikus/hari + air seduhan daun sirih dosis $67,5 \mathrm{mg} / 150 \mathrm{grBB}$ tikus/hari) dan 6 kandang dengan label K3 (untuk yang diberi parasetamol dosis 375mg/ $150 \mathrm{grBB}$ tikus/hari + air seduhan daun sirih dosis $90 \mathrm{mg} /$ $150 \mathrm{grBB}$ tikus/hari).

Kemudian hasil diamati dengan melalui tahap pembedahan dan fiksasi, pembuatan preparat, dan tahap pengamatan dan penghitungan sel hati yang rusak.

Hasil penghitungan sel yang nekrosis diuji normalitas dan homogenitas, serta dianalisis menggunakan uji one way ANOVA untuk pengujian lebih dari dua kelompok dan melihat perbedaan jumlah sel hati yang rusak pada masing-masing kelompok perlakuan. Uji analisa data tersebut menggunakan program SPSS 12 for Windows. Uji lanjut menggunakan uji Korelasi untuk mengetahui adanya hubungan antara pemberian air seduhan daun sirih terhadap prosentase sel hati yang rusak pada masing-masing kelompok perlakuan dan uji Regresi untuk mengetahui pengaruh air seduhan daun sirih terhadap prosentase sel hati yang rusak.

\section{HASIL DAN PEMBAHASAN}

Hasil penghitungan prosentase kerusakan hepatosit setelah diinduksi parasetamol dan diberi air seduhan daun sirih dapat dilihat pada tabel 1.

\section{Tabel 1. Prosentase Hepatosit Rusak Dalam} Persen (\%) Setelah Perlakuan

\begin{tabular}{|c|c|c|c|c|c|c|c|}
\hline \multirow{2}{*}{ Perlakuan } & \multicolumn{5}{|c|}{ Ulangan } & \multirow{2}{*}{\multicolumn{2}{|c|}{ Rerata }} \\
\hline & 1 & 2 & 3 & 4 & 5 & & \\
\hline & 40.532 & 42.752 & 37.209 & 40.286 & 44.957 & & \\
\hline $\mathrm{K}+\mathrm{A}$ & & & & & & 41.14720 & 2.903425 \\
\hline $\mathrm{K}+\mathrm{B}$ & 35.309 & 40.334 & 38.242 & 38.268 & 38.887 & 38.20800 & 1.829609 \\
\hline $\mathrm{K} 1$ & 36.482 & 29.643 & 34.912 & 39.620 & 38.321 & 35.79560 & 3.876534 \\
\hline K2 & 27.864 & 27.121 & 30.261 & 32.193 & 32.754 & 30.03860 & 2.515232 \\
\hline $\mathrm{K} 3$ & 21.421 & 20.442 & 22.536 & 21.050 & 20.241 & 21.13800 & 0.912587 \\
\hline
\end{tabular}

Dari hasil penghitungan rata-rata prosentase hepatosit rusak pada masingmasing perlakuan dapat dilihat pada grafik di bawah ini :

\section{Grafik 1. Grafik Rata-Rata Prosentase Hepatosit}

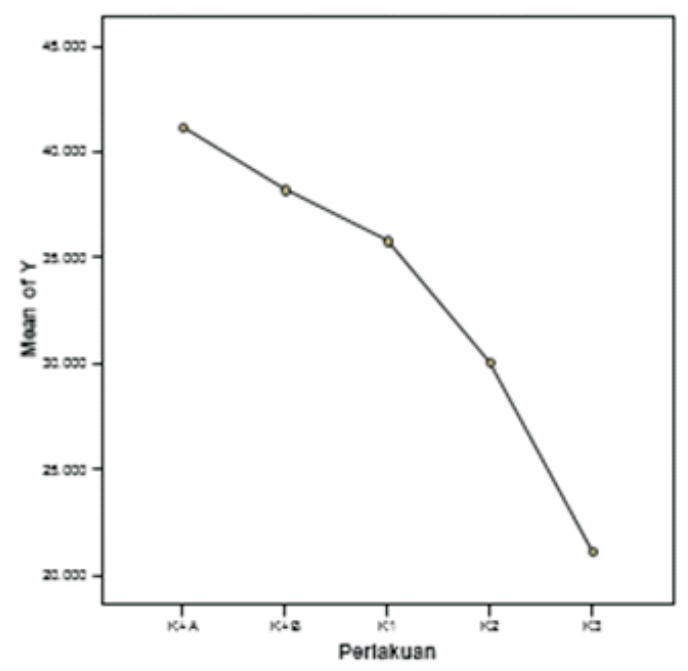

Sumber: Data primer yang diolah (2011)
Dari tabel dan diagram diatas dapat kita ketahui ratarata prosentase hepatosit yang rusak pada tiap kelompok perlakuan. Ada perbedaan rata-rata prosentase hepatosit rusak pada masing-masing kelompok perlakuan. Rata-rata prosentase pada $\mathrm{K}+\mathrm{B}$ mengalami penurunan tapi tidak sebesar penurunan pada kelompok K1, K2 dan K3. Ratarata prosentase paling rendah didapatkan pada kelompok perlakuan dengan dosis air seduhan daun sirih paling tinggi (K3). Hal ini menunjukkan ada penurunan rata-rata prosentase hepatosit yang rusak seiring dengan kenaikan dosis yang diberikan.

Hasil foto hepatosit tikus putih dengan pengecatan hematoksilin eosin dari masing-masing kelompok dapat dilihat pada gambar di bawah ini :

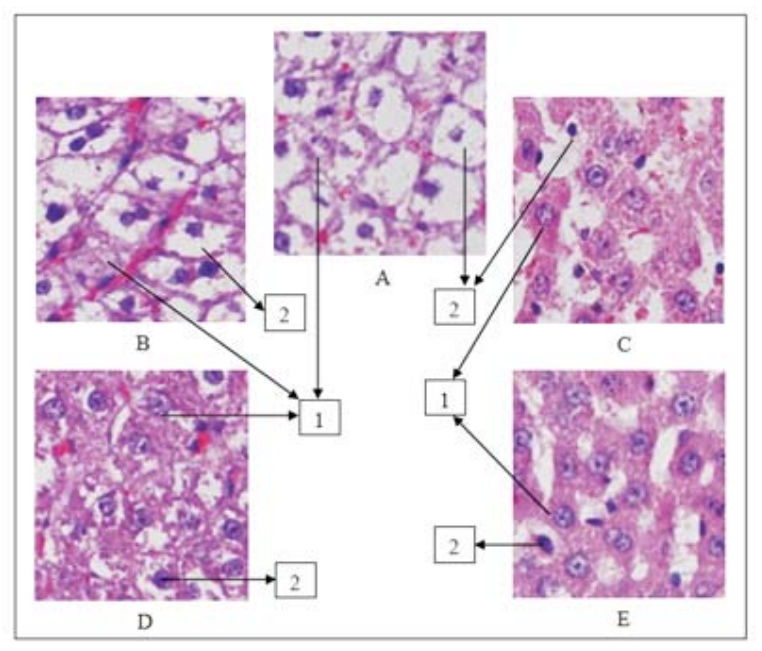

Gambar 1. Gambaran Hepatosit Tikus.

A. Kelompok $\mathrm{K}+\mathrm{A}$ (parasetamol $375 \mathrm{mg} / 150 \mathrm{grBB}$ tikus)

B. Kelompok $\mathrm{K}+\mathrm{B}$ (parasetamol $375 \mathrm{mg} / 150 \mathrm{grBB}$ tikus + pakan biasa 12 hari)

C. Kelompok K1 (parasetamol 375mg/150grBB tikus + air seduhan daun sirih $45 \mathrm{mg} / 150 \mathrm{grBB}$ tikus)

D. Kelompok K2 (parasetamol $375 \mathrm{mg} /$ grBB tikus+air seduhan daun sirih $67,5 \mathrm{mg} / 150 \mathrm{grBB}$ tikus)

E. Kelompok K3 (parasetamol+air seduhan daun sirih $90 \mathrm{mg} / 150 \mathrm{grBB}$ tikus

(1) Hepatosit dalam batas normal ditandai bengkak, nukleus membesar, sitoplasma bervakuol tapi masih bergranuler

(2) Hepatosit rusak dengan bengkak, nuklues piknotik yang hitam, memadat dan mengkerut serta sitoplasma dipenuhi vakuol.

Prosentase rata-rata kerusakan hepatosit yang paling tinggi adalah pada kelompok perlakuan $\mathrm{K}+\mathrm{A}$ yaitu kelompok yang diberi parasetamol dengan dosis $375 \mathrm{mg} / 150 \mathrm{grBB}$ selama 4 hari dan langsung dibedah pada hari ke 5 . Hal ini sesuai dengan teori bahwa parasetamol merusak hepatosit dengan menghasilkan metabolitnya berupa N-asetilpbenzokuinone imine (NAPQI) dan juga menghasilkan ion superoksida yang keduanya bersifat reaktif. NAPQI berikatan secara kovalen dengan makromolekul protein hepatosit, sedangkan ion superoksida berubah menjadi radikal hidroksil yang akan mengikat lipid serta protein membran hepatosit. Mekanisme ini akan menyebabkan 
terjadinya disfungsi sistem enzim, peroksidasi lipid dan protein membran hepatosit yang akan merusak membran hepatosit dan berlanjut dengan kerusakan hepatosit (Sastrowardoyo, 2004). Hal ini juga sesuai dengan penelitian yang pernah dilakukan Heirmayani pada tahun 2007 tentang pengaruh pemberian parasetamol terhadap hati dan ginjal tikus. Hasil pada penelitiannya parasetamol menimbulkan kerusakan sebanding dengan dosis yang diinduksikan (Heirmayani, 2007).

Hasil rata-rata prosentase pada kelompok perlakuan $\mathrm{K}+\mathrm{B}(38,208 \%)$ mengalami penurunan dibandingkan dengan hasil rata-rata prosentase kelompok perlakuan $\mathrm{K}+\mathrm{A}$ $(41,147 \%)$. Ini membuktikan bahwa ada perbaikan pada hepatosit yang telah dibiarkan dan hanya diberi pakan biasa jika dibandingkan dengan hepatosit yang hanya diberi parasetamol dan langsung dibedah. Hal ini sesuai dengan teori yang menyatakan bahwa hati mempunyai kemampuan regenerasi yang sangat bagus dan cepat. Pada hati tikus yang telah dilakukan hepatektomi parsial sampai $70 \%$, terjadi regenerasi dalam waktu 5 sampai 7 hari untuk kembali pada keadaan semula (Guyton, 2008).

Penurunan hasil rata-rata prosentase dari kelompok $\mathrm{K}+\mathrm{A}$ ke kelompok $\mathrm{K}+\mathrm{B}$ tidak sebesar penurunan dari kelompok $\mathrm{K}+\mathrm{A}$ ke kelompok $\mathrm{K} 1, \mathrm{~K} 2$ dan $\mathrm{K} 3$ yang telah diberi air seduhan daun sirih. Pada kelompok $\mathrm{K}+\mathrm{A}$ ratarata prosentase kerusakan hati sebesar $41,147 \%$ dan pada kelompok K1 yang telah diberi sir seduhan daun sirih dosis I rata-rata prosentase kerusakan hati turun sampai 35,796\%. Dan pada kelompok K2 dan K3 yang telah diberi air seduhan daun sirih dosis II dan III, ratarata prosentase kerusakan hepatosit semakin menurun yaitu 30,039\% dan $21,138 \%$. Jika dihubungkan maka hasil dari penelitian ini sesuai dengan teori bahwa air seduhan daun sirih mengandung minyak atsiri yang mana didalamnya terdapat kandungan senyawa yang diduga berperan sebagai antioksidan, antara lain hydroxychavicol, eugenol, piperol A dan B, piper betol, thiosianat, phenol, polifenol, alkaloid, steroid, saponin dan tannin (Choundhary, 2002; Tripathi, 2006; Arambewela, 2006). Senyawa-senyawa yang berperan sebagai antioksidan akan memberikan atom hidrogen dari gugus fungsi $-\mathrm{OH}$ (hidroksil) bebas milik mereka kepada radikal hidroksil dan metabolit reaktif yang terbentuk dari metabolisme parasetamol dosis toksik. Hal itu menyebabkan senyawa-senyawa yang reaktif tersebut menjadi stabil, sehingga tidak terjadi disfungsi sistem enzim serta peroksidasi lipid dan protein pada membran hepatosit yang nantinya akan merusak hepatosit (Saravanan et al, 2002).

Penelitian ini juga sesuai dengan penelitian yang pernah dilakukan Saravanan et al pada tahun 2002 yang membuktikan bahwa daun sirih dengan konsentrasi 100, 200 dan $300 \mathrm{mg} / \mathrm{kgBB}$ yang diberikan kepada mencit selama 30 hari menunjukkan penurunan aspartate aminotransferase (AST), alanin aminotransferase (ALT), thiobarbituric acid reactive substances (TBARS) dan hidroperoksida lipid karena minyak atsiri yang terkandung dalam daun sirih dapat membantu regenerasi hepatosit yang rusak. Penelitian lain yang dilakukan oleh Puntodewo pada tahun 2009 tentang daun sirih juga terbukti dapat menurunkan kadar SGOT, SGPT, GGT dan bilirubin secara signifikan pada tikus yang diinduksi parasetamol dosis toksik (Puntodewo, 2009).

Dengan hasil penelitian yang sudah diperoleh kita ketahui tiap peningkatan dosis air seduhan daun sirih yang diberikan dapat mengurangi rata-rata prosentase kerusakan hepatosit. Pada gambaran histologi hepatosit juga terjadi perbaikan pada kelompok yang diberi perlakuan air seduhan daun sirih (K1, K2 dan K3), dan perbaikan yang paling baik terdapat pada histologi hepatosit kelompok K3. Perbaikan histologi hepatosit ditandai dengan banyak hepatosit yang sitoplasmanya mulai granuler, ukuran hepatosit mulai mengecil ke bentuk normal dan inti sel yang sudah tidak piknotik. Berbeda dengan gambaran histologi hepatosit pada kelompok $\mathrm{K}+\mathrm{A}$, hampir semua hepatosit mengalami kerusakan yang ditandai dengan pembengkakan hepatosit, inti yang piknotik dan sitoplasma yang dipenuhi vakuol.

Nilai rata-rata prosentase kerusakan hepatosit dan gambaran histologi yang didapatkan pada kelompok yang diberi dosis air seduhan daun sirih paling besar yaitu dosis III (K3) belum mencapai keadaan hati normal, maka dari itu perlu dilakukan lagi penelitian dengan dosis air seduhan daun sirih yang lebih besar. Hal ini dilakukan dengan harapan tingkat prosentase kerusakan hepatosit dapat ditekan hingga angka normal dan gambaran histologi hepatosit mencapai keadaan normal.

Air seduhan daun sirih digunakan sebagai alternatif antioksidan alami karena manfaat dari kandungan minyak atsirinya yang berperan sebagai antioksidan. Selain itu alternatif ini relatif lebih aman, murah dan mudah diperoleh, karena dapat disediakan sendiri di rumah. Walaupun konsumsi daun sirih segar langsung dimakan lebih baik karena tidak ada kerusakan senyawa, tapi masyarakat sekarang tidak banyak melakukannya karena rasa dari daun sirih itu sendiri dan konsumsinya lebih mudah diminum daripada dikunyah. Pembuatan seduhan memudahkan masyarakat dalam mengkonsumsi daun sirih. Selain caranya yang sederhana, cara ini banyak dilakukan oleh masyarakat karena tidak diperlukannya alat khusus untuk pembuatannya seperti pada pembuatan ekstrak dan juga kerusakan senyawa yang terjadi relatif kecil. Bentuk seduhan juga lebih cepat terserap tubuh karena dalam bentuk larutan, sedangkan jika dimakan langsung maka perlu melalui proses pencernaan dulu dalam tubuh (Damayanti, 2004 dan Djubaedah 1995). Dengan berbagai kelebihan yang ada di dalamnya diharapkan air seduhan daun sirih menjadi antioksidan alami alternatif pilihan masyarakat.

\section{SIMPULAN}

Berdasarkan dari hasil penelitian yang telah dilakukan maka dapat ditarik beberapa kesimpulan yaitu pemberian air seduhan daun sirih (Piper betle. L) terbukti dapat memperbaiki histologi hepatosit pada tikus strain wistar yang telah diinduksi parasetamol. Peningkatan dosis air seduhan daun sirih (Piper betle. L) berbanding terbalik dengan prosentase kerusakan hepatosit pada tikus strain wistar yang telah diinduksi parasetamol. Semakin tinggi dosis air seduhan daun sirih yang diberikan maka prosentase kerusakan hepatosit semakin rendah. 


\section{DAFTAR PUSTAKA}

Amirudin Rifai, 2009, Fisiologi dan Biokimia Hati, In: Sudoyo AW, Setiyohadi B, Alwi Idrus, et al, Buku Ajar Ilmu Penyakit Dalam jilid 1 edisi 5, InternaPublishing, Jakarta, hal 415-419

Arambewela L, Arawwawala M, Rajapaksa D, 2006, Piper betle : A Potential Natural Antioxidant. Original Article. International Journal of Food Science Supl 41:10-14

Arief Sjamsul, 2009, Radikal Bebas, FK UNAIR, Surabaya Bayupurnama Putut, 2009, Hepatotoksisitas Imbas Obat, In: Sudoyo AW, Setiyohadi B, Alwi Idrus, et al, Buku Ajar Ilmu Penyakit Dalam jilid 1 edisi 5, InternaPublishing, Jakarta, hal 471-474

Bloom \& Fawcett, 2002, Buku Ajar Histologi edisi 12, EGC, Jakarta

Choundhary D, Kale RK, 2002, Antioxidant and Non-Toxic Properties of Piper betle Leaf Extract: in Vitro and in Vivo Studies, Phytotherapy Research 16: 461-466

Damayanti R, Mulyono, 2004, Khasiat dan Manfaat Daun Sirih, Agromedia Pustaka, Jakarta

Dasgupta N, Bratati D. 2004. Antioxidant activity Piper betle L. leaf extract in vitro. Food Chemistry 88 (2): 219-224

Djatmiko, Santoso, M.H., dan Wahyo, 1998, Seminar Nasional Tumbuhan Obat XII, Fakultas Farmasi Unair, Surabaya.

Djubaedah Ebet, et al, 1995, Materia Medica Indonesia jilid I cetakan pertama, Departemen Kesehatan Republik Indonesia, Jakarta

Dugan, L. R 1985. Natural Antioxidants. Di dalam M. G. Simic dan Karel (eds.). Autooxidation in Food and Biological System. Ple1lllum Press, New York

Duke JA, Bogenschutz-Godwin MJ, Cellier J du, et al, 2002, Handbook of Medicinal Herbs, Edisi kedua, CRC Press, New York

Elvina, 2004, Antioksidan Resep Sehat dan Kesehatan, diakses tanggal 20 juli 2010 http:/www. Antioksidan.net//htm

Eroschenko VP Ph.D, 2003, Atlas Histologi di Fiore dengan Korelasi Fungsional edisi 9, EGC, Jakarta

Goodman, Gilman, 2008, Dasar Farmakologi Terapi volume 1 edisi 10, EGC, Jakarta, hal 682-684

Guyton AC, Hall, 2008, Buku Ajar Fisiologi Kedokteran edisi 11, EGC, Jakarta

Handajani, Fitri, 2008, Pengaruh Pemberian Ekstrak Buah Merah (Pandanus conoideus lam) Pada Kadar SGPT Dan Y-GT tikus putih yang diinduksi Parasetamol Dosis Tinggi, Jurnal Airlangga University Library, Surabaya

Hariana A, 2006, Tumbuhan Obat dan Khasiatnya Seri 3, Penerbit, Penebar Swadaya, Jakarta

Hayati F, et al, 2009, uji toksisitas tablet Effervescent dari ekstrak daun sirih (Piper betle L.) pada tikus putih jantan strain wistar, Fakultas Farmasi Universitas Gadjah Mada, Yogyakarta

Heyne K, 1987, Tumbuhan Berguna Indonesia II, Badan Penelitian dan Pengembangan Kehutanan. Departemen Kesehatan Republik Indonesia, Jakarta

Heirmayani, 2007, Toksikopatologi Hati Mencit (Mus Musculus) pada Pemberian Parasetamol, Fakultas Kedokteran Hewan Institut Pertanian Bogor, Bogor
Hernani, Raharjo M. 2005. Tanaman Berkhasiat Antioksidan. Jakarta: Penebar Swadaya

Ho, C. T. 1992. Phenolic Compounds: An Overview. Di dalam Huang, M. T., Ho, C. T. dan Lee, C. Y. (eds.). Phenolic Compound in Food and Their Effect on Health 1. American Chemical Society, Washington

Horn Tim, Learned James, 2005, Hepatitis Virus dan HIV, Yayasan Spiritia, Jakarta

Ihsan, 2007, Mengenal Lebih Dekat Hepatitis, diakses tanggal 28 Juli 2010, http://www.ayruzallein.co.cc/2010/07/ mengenal-lebih-dekathepatitis.html.

Isadiartuti Dewi, Sari Retno, 2006, Studi Efektivitas Sediaan Gel Antiseptik Tangan Ekstrak Daun Sirih, Fakultas Farmasi Universitas Airlangga, Surabaya

Kochhar, S. P. dan Rossel, J. B. 1992. Detection, Estimation and Evalnation of Antioxidants in Food Systems. Di dalam Hudson, B. J .. F. (ed.). Food Antioxidants. Elsevier Applied Sci., New York

Larson, R. A. 1988. The antioxidants of higher plants. Phytochern. 27 : 969

Lim PH, Mohamed S. 1999. Antioxidative and antimycotic effects of turmeric, lemon-grass, betel leaves, clove, black pepper leaves and garcinia atriviridis on butter cakes. Journal of the Science of Food and Agriculture 79: 18171822

Linawati Y, Apriyanto A, Susanti E ,et al, 2000, Efek Hepatoprotektif Rebusan Herba Putri-Malu (Mimosa pigra, L.) pada Tikus Terangsang Parasetamol, fakultar Farmasi Universitas Gadjah Mada, Yogyakarta

Mayorita F, 2006, Efek Dekok Daun Sambiloto (Andrographis paniculata) terhadap Kadar SGOT dan SGPT pada Tikus Putih (Rattus novergicus strain wistar) yang Diinduksi dengan Karbon Tetraklorida (CC14), Karya Tulis Akhir, Universitas Muhammadiyah Malang, Malang

Moeljatno, R., 2003, Khasiat dan Manfaat Daun Sirih Obat Mujarab dari Masa ke Masa, Agromedia Pustaka, Jakarta

Moure A et al. 2001. Natural antioxidant from residual resources. Food Chemistry, 72:145-171

Murray RK, Granner DK, Mayes PA, Rodwell VW, 2003, Biokimia Harper Ed ke 25, Hartanto A, penerjemah. Jakarta: EGC. Terjemahan dari: Harper?s Biochemistry

Noorcholies Z., Wahjo D., dan Mulja H.S., 1997, Proses Bahan Tanaman Menjadi Obat di Indonesia, Surabaya

Notoatmodjo Prof Dr S, 2010, Metodologi Penelitian Kesehatan, Rineka Cipta, Jakarta

Pabst R, Putz R, 2000, Aatlas Anatomi Manusia Sobotta jilid 2 edisi 21, EGC, Jakarta, hal 142

Pakarti AW, 2009, Pengaruh Perasan Buah Mangga terhadap Farmakokinetika Parasetamol yang Diberikan Bersama secara Oral pada Kelinci Jantan, Fakultas Farmasi Universitas Muhammadiyah Surakarta, Surakarta

Parwata O H, et al, 2009, Isolasi dan Uji Antiradikal Bebas Minyak Atsiri pada Daun Sirih (Piper betle Linn) Secara Spektroskopi Ultra Violet-Tampak, Jurusan Kimia FMIPA Universitas Udayana, Bukit Jimbaran

Pudjaatmaka A, Hadyana, 2002, Kamus Kimia, Penerbit Balai Pustaka, Jakarta 
Puntodewo GA, 2009, Pengaruh Air Seduhan Daun Sirih Terhadap Kadar GGT (Gamma Glutamil Transferase) Hepar Studi Eksperimen pada Tikus Putih Jantan Galur Wistar yang Diinduksi Parasetamol, Fakultas Kedokteran Universitas Islam Sultan Agung, Jawa Tengah

Rahmawati, D., 2004, Uji Antiradikal Bebas Senyawa Golongan Flavonoid pada Ekstrak Metanol Buah Mengkudu (Morinda Citrifolia L.) Secara Spektroskopi, Jurusan Kimia, FMIPA, Universitas Udayana, Denpasar

Ranney, M. W. 1979. Antioxidant Recent Development. Noyes Data Co., Park Ridge, USA

Rao S, Rao S. 1964. Syntesis of 4-allylcatechol \& mechanism of claisen rearrangement in catechols. Ind J Chem 2 : 323-327

Santhakumari P, Prakasam A, Pugalendi KV. 2003. Modulation of oxidative stress parameters by treatment with Piper betle Leaf in streptozotocin induced diabetic rats. Indian Journal of Pharmacology 35: 373-378

Saravanan R, Prakasam A, Ramesh B, Pugalendi KV, 2002, Influence of Piper betle on Hepatic Marker Enzymes and Tissue Antioxidant Status in Ethanoltreated Wistar Rats, Journal of Medicinal Food 5 (4): 197-204

Sastrowardoyo, Sudjarwo, 2004, Potensi Ekstrak Buah Mengkudu Sebagai Hepatoprotektor Pada Mencit yang Diberi Parasetamol, Jurnal Medika No.5 tahun 2004

Sugiastuti S. 2002. Kajian aktivitas antibakteri dan antioksidan ekstrak daun sirih (Piper betle L.) pada daging giling [tesis]. Bogor: Program Pascasarjana, Institut Pertanian Bogor

Supranto J, 2007, Teknik Sampling Survey \& Eksperimen, Rineka Cipta, Jakarta

Suryohudoyo, 2002, Kapita Selekta Ilmu Kedokteran Molekuler, CV Indomedika, Jakarta

Tripathi S, et al, 2006, Landrace/Gender-Based Differences in Phenol and Thiocyanate Contents and Biological Activity in Piper betle Linn. Current Science 91 (6): 746749

Ulfa Maria, 2008, Efek Hepatoprotektif Ekstrak Etil Asetat Daun Sambung Nyawa (Gynura procumbens (Lour.) DC.) terhadap Mencit Jantan Galur Swiss Terinduksi Parasetamol, Fakultas Farmasi Universitas Muhammadiyah Surakarta, Surakarta

Wahyu S, 2009, Sisten Enterohepatik, diakses tanggal 9 Mei 2010 .http: / / www.docstoc.com/docs / DownloadDoc.aspx?doc_id=37021376\&ref_url

Wong, D. W. S. 1989. Mechanism and Theory in Food Chemistry. Van Nostrand Reinhold, New York

Zuraidah zulkarnain, Julfina Bisanto, Purnamawati S.P, et al, 2000, Tinjauan Komprehensif Hepatitis Virus pada Anak, Balai Penerbit FKUI, Jakarta 